\title{
Association of matrix metalloproteinases 3 and 9 single nucleotide polymorphisms with breast cancer risk: A case-control study
}

\author{
FAWZIYA ABD ELMAOGOUD RAGAB IBRAHIM ${ }^{1 *}$, SHAYMAA ESSAM ELFEKY $^{2 *}$, \\ MEDHAT HAROUN $^{3}$, MOHAMED ABD ELRAHMAN AHMED ${ }^{4}$, MOSTAFA ELNAGGAR ${ }^{5}$, \\ NADA ABD ELFATAH ISMAIL ${ }^{3}$ and NADIA AHMED ABD EL MONEIM ${ }^{5}$
}

\begin{abstract}
Departments of ${ }^{1}$ Applied Medical Chemistry and ${ }^{2}$ Radiation Sciences, Medical Research Institute, University of Alexandria, Alexandria 21561; ${ }^{3}$ Department of Biotechnology, Institute of Graduate Studies and Research, University of Alexandria, Alexandria 21526; ${ }^{4}$ Department of Clinical Pathology, Medical Military Academy, Alexandria 21615; ${ }^{5}$ Department of Cancer Management and Research, Medical Research Institute, University of Alexandria, Alexandria 21561, Egypt
\end{abstract}

Received May 5, 2019; Accepted January 15, 2020

DOI: $10.3892 / \mathrm{mco} .2020 .2041$

\begin{abstract}
Two single nucleotide polymorphisms (SNPs) of matrix metalloproteinase (MMPs) 3 and 9 are functionally implicated in the progression of various types of cancer, including breast cancer (BC). However, the roles of these SNPs remain controversial. In addition, they also vary between one population and another. Therefore, the present study aimed to investigate the possible association between MMP3-1171 5A/6A and MMP9-1562 CT SNPs and the risk of BC among Egyptians, and to elucidate the alteration of MMP3 and MMP9 gene expression in patients with $\mathrm{BC}$. The present case-control study enrolled 162 patients with $\mathrm{BC}$ and 146 control subjects. Restriction fragment length polymorphism-PCR was performed for analysis of the selected SNPs, gene expression of MMP3 and MMP9 was also assessed in 50 patients and 50 control subjects by reverse transcription-quantitative PCR. The frequencies of 5A/6A genotype and 5A allele of MMP3 were significantly higher in patients with $\mathrm{BC}$ compared with in healthy subjects. On the other hand, the distributions of MMP9 genotypes and alleles were not significantly different among patients and healthy subjects. Compared with healthy
\end{abstract}

Correspondence to: Dr Fawziya Abd Elmaogoud Ragab Ibrahim, Department of Applied Medical Chemistry, Medical Research Institute, University of Alexandria, 165 Elhorreya Avenue, El-Hadara, Alexandria 21561, Egypt

E-mail: d.fawziyaibrahim@gmail.com

Abbreviations: BC, breast cancer; SNPs, single nucleotide polymorphisms; MMP, matrix metalloproteinase; RT-qPCR, reverse transcription-quantitative PCR; HWE, Hardy Weinberg Equation; ER, estrogen receptor; PR, progesterone receptor; Her-2, human epidermal growth factor receptor 2

*Contributed equally

Key words: single nucleotide polymorphisms, matrix metalloproteinase, breast cancer, risk factor, Egyptian subjects, the expression levels of the two genes were found to be upregulated in patients with BC. Therefore, the present study indicated that MMP3-1171 5A/6A SNP, not MMP9-1562 C $>$ T SNP may be a risk factor for developing BC among Egyptian females.

\section{Introduction}

Worldwide, breast cancer (BC) is the most frequently diagnosed cancer and it is the primary cause of cancer-deaths among females (1). In Egypt, BC is the prevalent female cancer with a percentage of about $38.8 \%$ of all cancers types in women, with increasing mortality rates (up to $1.3 \%$ in the years from 2000 to $2011(2,3)$. The risk for developing BC has been reported to be associated with many susceptible single nucleotide polymorphisms (SNPs) $(4,5)$. Therefore, deep insights into the mechanisms underlying the involvement of SNPs in cancer susceptibility may lead to better understanding of the molecular pathogenesis of the disease. Moreover, SNPs can be implicated as powerful biomarkers in the prediction and therapy of various cancer diseases (6).

Two integral members of matrix metalloproteinase (MMPs', family MMP3, and MMP9) have a crucial role in the development and metastasis of cancer. MMP3 is a $54 \mathrm{kDa}$ enzyme synthesized in the connective tissue, leading, subsequently; to the activation of other MMPs such as gelatins $\mathrm{B}$ and the release of some cell surface molecules including E cadherin. Furthermore, it is implicated in the degradation of many extra cellular components such as collagen III and IV, which may render it as an effective tumor promoter (7). MMP9 is the most complex enzyme of MMPs family with $92 \mathrm{kDa}(8)$, where, under physiological conditions, it binds to gelatin, collagen and laminin of matrix leading to their degradation. However, in pathologic conditions, this function mediates tumor invasion (9).

The role of MMP genes functional polymorphisms in cancer susceptibility has been previously investigated. However, better understanding of the association between MMPs SNPs and BC pre-disposition and prognosis still needs further studies (10). Actually, some of promoter-located SNPs 
may lead to allele-specific effects on the expression of MMPs such as-1562 $\mathrm{C}>\mathrm{T}$ substitution in MMP9 promoter (11), and adenosine-insertion/deletion-at position-1171 in the MMP3 promoter sequence (12). Consequently, these two SNPs attracted researchers to study their possible roles in the progression of BC. However, to the best of our knowledge, the published results, regarding the association between both SNPs and BC risk is still inconclusive and controversial as it had been reported that they vary greatly from one population to another, along with the lack of previous studies investigating such association in the Egyptian population, which urged us to investigate the possible association between both MMP3-1171 5A/6A and MMP9-1562 C/T SNPs with BC susceptibility among a sample of Egyptian females.

\section{Materials and methods}

This case-control study enrolled 162 BC patients and 146age-matched cancer-free women. Patients were recruited from Cancer Management and Research Department, Medical Research Institute and Ayadi Al-Mostakbal Hospital (Alexandria-Egypt). In addition, research methodology and sampling in this work were approved by the Research Ethic Committee, Medical Research Institute/Alexandria University. Prior to sample collection, an informed consent was obtained from each participant enrolled in the study. Clinicopathological data of patients including age, pathological type, grade, lymph node status, ER, PR and Her-2 status were also collected. A blood sample from each participant was withdrawn on EDTA-coated tube and stored at $-80^{\circ} \mathrm{C}$ till time of investigations.

DNA extraction. Extraction of genomic DNA was performed using Invitrogen Pure Link Genomic DNA mini kit (Thermo Fischer Scientific, Inc.) following manufacturer instructions. Assessment of DNA purity and concentration were performed by measuring sample absorbance at 260/280 nm with Nano Drop $^{\circledR}$ ND-1000 UV-Visible Spectrophotometer (Thermo Fischer Scientific, Inc.). The extracted DNA was stored at $-20^{\circ} \mathrm{C}$ till genotyping.

Genotyping of MMP3-1171 5A/6A SNP. Restriction fragment length polymerase chain reaction was performed for genotyping of MMP3. DNA was amplified by PCR using BIO-RAD T100 Thermal-cycler (Thermo Fischer Scientific, Inc.). The reaction was carried-out in a final volume of $25 \mu \mathrm{l}$ consisting of $12.5 \mu \mathrm{l}$ of 2x Dream Taq green master mix with dual dye (Thermo Fischer Scientific, Inc.), $100 \mathrm{ng}$ DNA template and $0.5 \mu \mathrm{mol}$ of forward/reverse primer (13) (Table I). The thermal profile was as follows: 3 min initial denaturation at $94^{\circ} \mathrm{C}$, followed by 35 cycles of denaturation for $30 \mathrm{sec}$ at $95^{\circ} \mathrm{C}$, annealing at $56.1^{\circ} \mathrm{C}$ for $30 \mathrm{sec}$, and extension at $72^{\circ} \mathrm{C} 30 \mathrm{sec}$, then a final extension at $72^{\circ} \mathrm{C}$ for $10 \mathrm{~min}$. For digestion; $10 \mu \mathrm{l}$ of PCR products were incubated with $5 \mathrm{U}$ of the enzyme PsyI (Promega Corporation) for $2 \mathrm{~h}$ at $37^{\circ} \mathrm{C}$. After digestion, the different genotypes of MMP3 were visualized on $3 \%$ agarose gel, the homozygous 6A/6A genotype produced a large fragment at 129 bp whereas the homozygous 5A/5A genotype had shorter fragments at 97 and $32 \mathrm{bp}$. Heterozygote 5A/6A genotype generated three bands at 129, 97 and 32 bp (Fig. 1A).
Genotyping of MMP9-1562 C/T. For the analysis of MMP9-1562C/T polymorphism, PCR was carried out in $25 \mu \mathrm{l}$ reaction volume as described previously using the suitable primers pair (14). The PCR cycling conditions were as follows: $3 \mathrm{~min}$ of initial denaturation at $95^{\circ} \mathrm{C}$, then 35 cycles of denaturation for $30 \mathrm{sec}$ at $95^{\circ} \mathrm{C}$, then annealing for $30 \mathrm{sec}$ at $58^{\circ} \mathrm{C}$ and extension for $30 \mathrm{sec}$ at $72^{\circ} \mathrm{C}$, followed by $10 \mathrm{~min}$ at $72^{\circ} \mathrm{C}$ as final extension. For digestion, $10 \mu \mathrm{l}$ the PCR product were incubated with $5 \mathrm{U}$ of the restriction enzyme Sph1 (Promega Corporation) at $37^{\circ} \mathrm{C}$ for $2 \mathrm{~h}$. Upon digestion, The CC genotype produces single large fragment at $460 \mathrm{bp}$, whereas TT genotypes produces shorter fragment at $202 \mathrm{bp}$, and the heterozygote genotype $\mathrm{CT}$ generates a combination of three fragments (460 bp, 202 bp and 258 bp bands).

MMP3 and MMP9 gene expression. MMP3 and MMP9 gene expression was investigated in 50 patients and 50 cancer-free control subjects. Total RNA was extracted from the whole blood using Invitrogen PureLink RNA mini kit, following the manufacturer's instructions. Purity of the extracted RNA was assessed via NanoDrop ${ }^{\circledR}$ ND-1000 UV-Visible Spectrophotometer (both from Thermo Fischer Scientific). Reverse transcription-quantitative PCR was performed using Top real TM one step RT-qPCR kit (SYBRGreen with low ROX.RT qPCR). PCR was performed using $10 \mu 1$ reaction mix, $2 \mu 1$ of RNA, $1 \mu 1$ of each appropriate primer (15) (Table I), $1 \mu 12 \mathrm{x}$ enzyme mix and $5 \mu \mathrm{l}$ of water. The thermal profile was as follows: Hold $30 \mathrm{~min}$ at $50^{\circ} \mathrm{C}$, initial denaturation $10 \mathrm{~min} 95^{\circ} \mathrm{C}$, followed by 45 cycles of a denaturation step at $95^{\circ} \mathrm{C}$ for $5 \mathrm{sec}$ and an annealing step at $50^{\circ} \mathrm{C}$ for $30 \mathrm{sec}$. qPCR reactions were carried out in duplicates for each sample, then the relative expression of MMP3 and MMP9 was normalized to GAPDH as a house keeping gene and fold-change was calculated with the $2^{-\Delta \Delta \mathrm{Cq}}$ method (16).

Statistical analysis. Statistical analyses were carried out using SPSS 22.0 software. Hardy Weinberg equation (HWE) was performed to compare the frequencies of observed to expected genotype in the studied groups, Chi Square $\left(\chi^{2}\right)$ test used to compare genotypes distribution between the two study groups. The association between different genotypes and cancer risk was assessed by calculating odd ratio (OR) at corresponding $95 \%$ confidence interval (95\% CI). Kruskal Wallis test was used to analyze the variation of gene expression among different genotypes of MMP3 and MMP9. The associations between both of different genotypes of MMP3, MMP9 and gene expression with the clinicopathological characteristics were analyzed using Chi Square $\left(\chi^{2}\right)$ test. Kaplan-Meier analysis was used to study the associations between the different genotypes of MMP3 and MMP9 and disease-free and overall survival rates. $\mathrm{P}<0.05$, was statistically considered significant.

\section{Results}

Clinicopathological characteristics of patients. The clinicopathological parameters of all patients are represented in Table II. Concerning the histological grade, about three quarters of patients were of grade II, whereas one quarter 
Table I. RFLP-PCR and reverse transcription-quantitative PCR primers for MMP3, MMP9 and GAPDH.

RFLP-PCR primers $\left(5^{\prime}-3^{\prime}\right)(13,14)^{\mathrm{a}}$

Reverse transcription-quantitative PCR primers $\left(5^{\prime}-3^{\prime}\right)(15)^{\mathrm{a}}$

$\begin{array}{ll}\text { MMP3 } & \text { F: CTTCCTGGAATTCACATCACTGCCACCACT } \\ & \text { R: GGTTCTCCATTCCTTTGATGGGGGGAAAGA } \\ \text { MMP9 } & \text { F: GCCTGGCACATAGTAGGCCC } \\ & \text { R: CTTCCTAGCCAGCCGGCATC }\end{array}$

GAPDH
F: GTCTCTTTCACTCAGCCAAC
R: ATCAGGATTTCTCCCCTCAG
F: CCTTCCTTATCGCCGACAAG
R: TGAACAGCAGCATCTTCCCC
F: GACCTGCCGTCTAGAAAAAC
R: TTGAAGTCAGAGGAGACCAC

${ }^{a}$ References for the primers used in RFLP-PCR and quantitative PCR. MMP, matrix metalloproteinase. RFLP-PCR, restriction fragment length polymorphism-PCR; GAPDH, glyceraldehyde 3-phosphate dehydrogenase; F, forward; R, reverse.

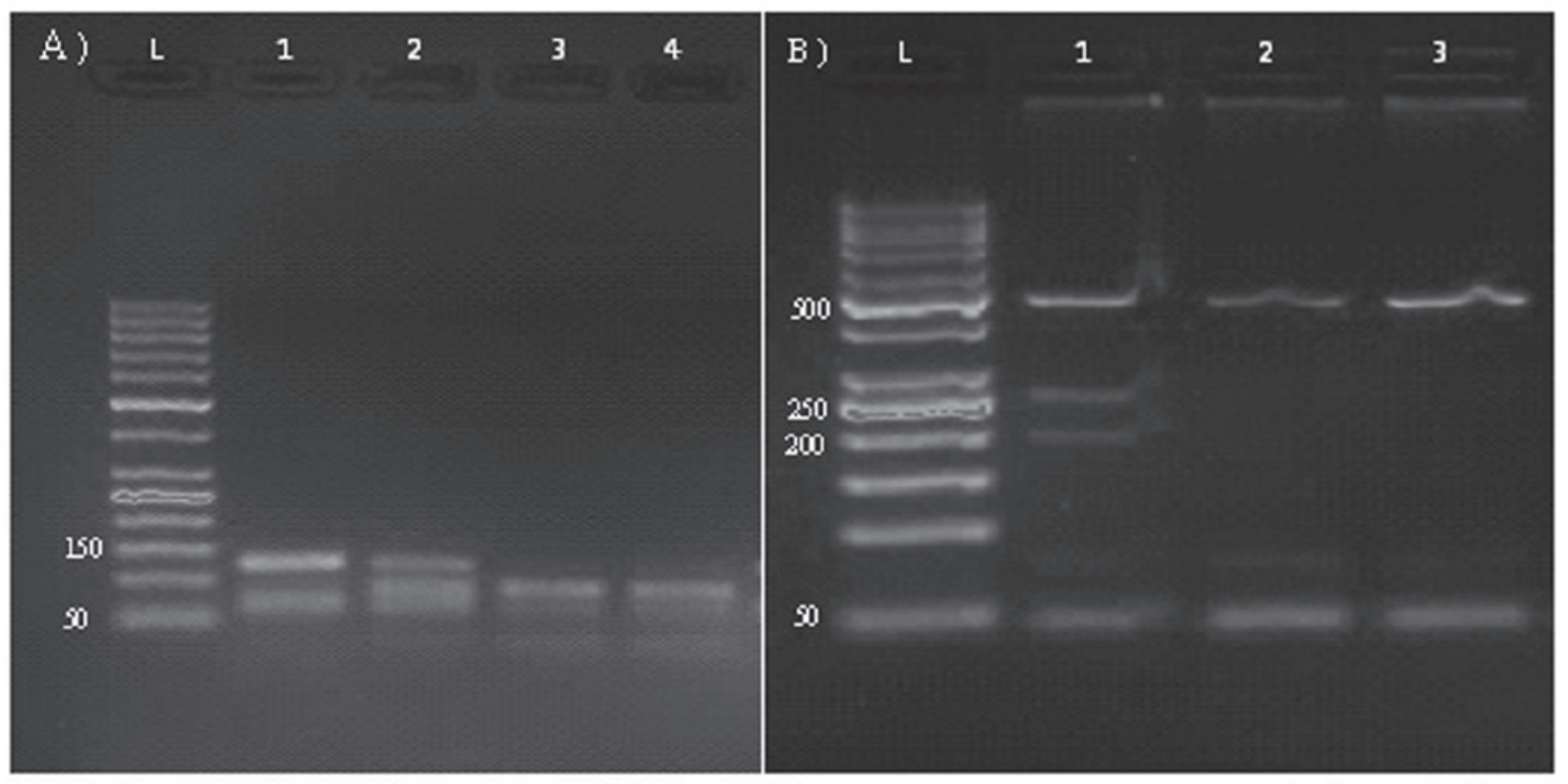

Figure 1. Agarose gel electrophoresis showing digestion of PCR products of MMP3 and MMP9 genes. (A) Agarose gel (3\%) stained with ethidium bromide revealing digestion of PCR product using the Psyl restriction enzyme. Lane L is a $50 \mathrm{bp}$ DNA ladder, lane 1 is the homozygous 6A/6A genotype, lanes 3 and 4 are homozygous 5A/5A genotype, lane 2 is the heterozygous 5A/6A genotype. (B) Agarose gel (2\%) stained with ethidium bromide revealing digestion of PCR product using $S p h \mathrm{I}$ restriction enzyme. Lane L is the 50 bp DNA ladder, lane 1 is the heterozygous CT genotype, and lanes 2 and 3 are the homozygous CC genotype.

of them were of grade III. With respect to pathology type, invasive ductal carcinoma was found in more than $95 \%$ of patients. More than half of patients had positive axillary lymph nodes. With regarding to receptors' status, positive ER and PR were found in more than half of patients, whereas almost two third of patients were negative to HER-2 expression, and no triple negative $\mathrm{BC}$ patients were found among enrolled patients.

Distribution of genotypes and allelic frequencies of MMP3-1171 5A/6A SNP. The genotypes distributions in the healthy females did not significantly differ from those predicted by HWE $(\mathrm{P}=0.164)$, in $\mathrm{BC}$ patients the distribution deviated from that expected by HWE $(\mathrm{P}=0.005)$. The distributions of MMP3 genotypes and allele frequencies are presented in Table III. Our results indicated a significant difference in distribution of $5 \mathrm{~A} / 6 \mathrm{~A}, 6 \mathrm{~A} / 6 \mathrm{~A}$, and $5 \mathrm{~A} / 5 \mathrm{~A}$ genotypes between $\mathrm{BC}$ patients and the healthy females groups $(\mathrm{P}=0.006,0.003$, and 0.011, respectively). Furthermore, results also indicated that both $5 \mathrm{~A} / 6 \mathrm{~A}$ and $5 \mathrm{~A} / 5 \mathrm{~A}$ genotypes are associated with higher $\mathrm{BC}$ risk $(\mathrm{OR}=2.545,95 \%$ $\mathrm{CI}=1.379-4.695, \mathrm{P}=0.0028, \mathrm{OR}=5.760,95 \% \mathrm{CI}=1.267-26.187$, $\mathrm{P}=0.0234$, respectively) as compared with $6 \mathrm{~A} / 6 \mathrm{~A}$ genotype. The odds ratio for $5 \mathrm{~A}$ allele indicated that it is associated with 3.021-fold increased $\mathrm{BC}$ risk as compared with the $6 \mathrm{~A}$ allele.

Distribution of genotype and allelic frequencies of MMP9-1562 C> T SNP. Fig. 1B shows only two genotypes of-1562 C>TMMP9 polymorphism, where no homozygote TT 
Table II. Clinicopathological parameters of patients with BC.

\begin{tabular}{lr} 
Clinicopathological & \\
parameters and characteristics & Patients, n $(\%)$ \\
\hline Histological grade & $121(74.7)$ \\
II & $41(25.3)$ \\
III & \\
Involved axillary lymph nodes & $67(41.4)$ \\
Negative & $95(58.6)$ \\
Positive & \\
Pathological type & $157(96.9)$ \\
Invasive ductal carcinoma & $5(3.1)$ \\
Invasive lobular carcinoma & \\
ER status & $54(33.3)$ \\
Negative & $108(66.7)$ \\
Positive & \\
PR status & $65(40.1)$ \\
Negative & $97(59.9)$ \\
Positive & \\
HER-2 status & $117(72.2)$ \\
Negative & $45(27.8)$ \\
Positive &
\end{tabular}

$\mathrm{BC}$, breast cancer; ER, estrogen receptor; PR, progesterone receptor.

genotype was found among the enrolled subjects in the study. The distribution of MMP9 genotypes did not deviate from those expected by HWE in both patients and control groups $(\mathrm{P}=0.287, \mathrm{P}=0.484$ respectively). The results represented in Table III indicated that the distribution of CC and CT genotypes did not significantly differ when comparing cancer patients and healthy women groups $(\mathrm{P}=0.249)$, the distribution of $\mathrm{C}$ and $\mathrm{T}$ alleles did not show any significant difference between cancer and control group $(\mathrm{P}=0.266)$. Furthermore, the results of this study also indicate that MMP9 polymorphism is not associated with $\mathrm{BC}$ risk, however, the $\mathrm{T}$ allele may be a weak risk factor for progression of the disease $(\mathrm{OR}=1.442$, 95\% CI=0.754-2.759).

Gene expression of MMP3 and MMP9. The gene expression of MMP3 showed an insignificant up regulation in patients as compared to the healthy subjects, however, the expression in patients with $5 \mathrm{~A} / 5 \mathrm{~A}$ genotype was about two times higher than6A/6A genotype patients (Fig. 2A). The expression of MMP9 in patients was significantly up regulated in patients $(\mathrm{P}=0.021)$. Moreover, the expression in CT genotype patients was found to be higher as compared to patients suffering from CC genotype (Fig. 2B).

Association of MMP3 and MMP9 gene polymorphisms and gene expression with clinicopathological features. Genotypes distribution of MMP3 and MMP9 polymorphisms with respect to patient's clinical characteristics are represented in Table IV. With regard to MMP3, 6A/6A genotype was associated with grade II. But, regarding lymph nodes (LNs) status, about half of
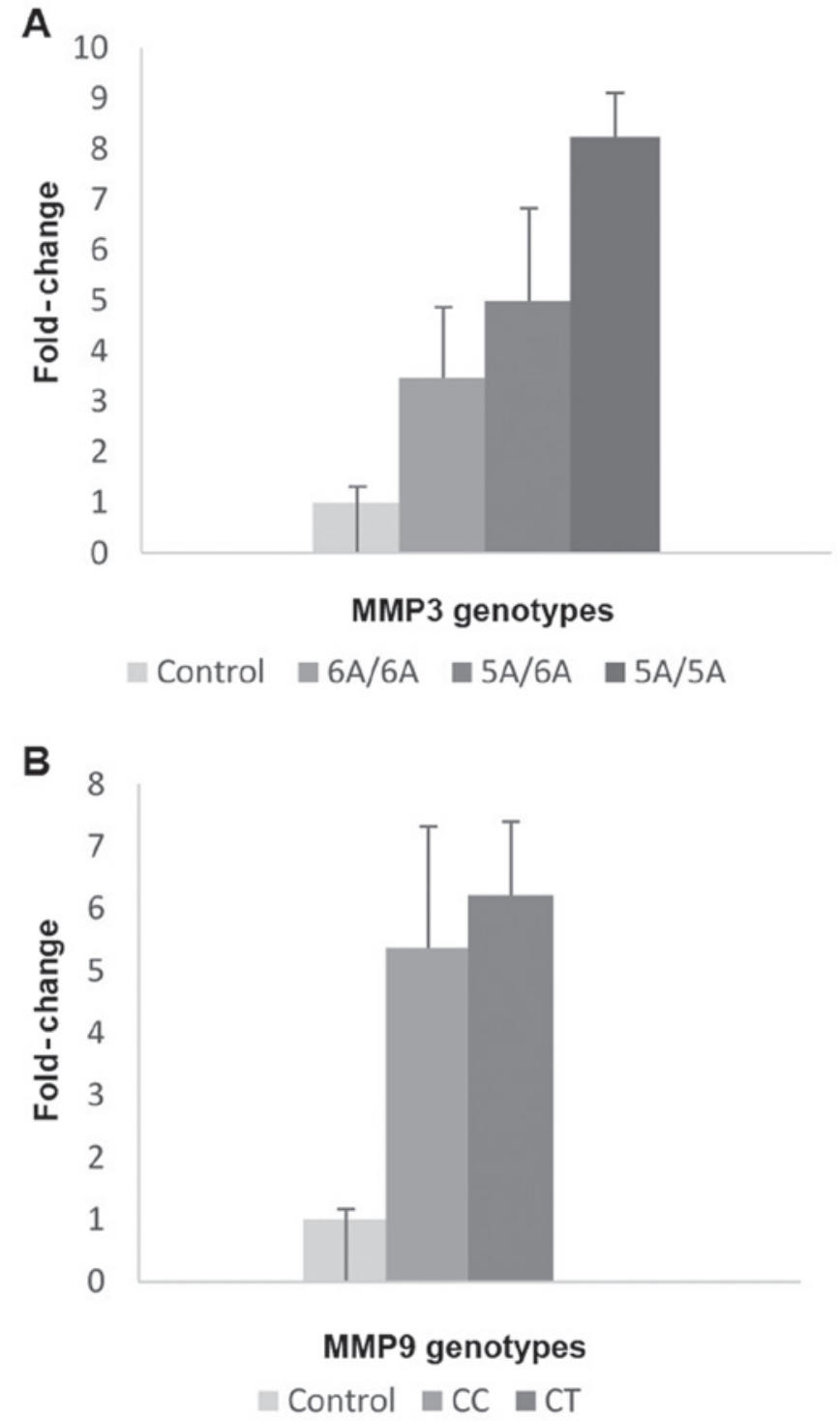

Figure 2. Fold-change in gene expression among different genotypes of (A) MMP3 and (B) MMP9 in 50 patients with BC compared with healthy subjects. Results are expressed as the mean \pm SEM. Kruskal Wallis test was used to analyze the variation of gene expression among different genotypes of MMP3 and MMP9. BC, breast cancer; MMP, matrix metalloproteinase.

patients with negative LNs were of 6A/6A genotype, and it was noted that $6 \mathrm{~A} / 6 \mathrm{~A}$ genotype was associated with the expression of ER, PR, and more than $50 \%$ of patients with positive Her-2 had 6A/6A genotype. With respect to MMP9, CC genotype was associated with the less aggressive pathological type grade II. Furthermore, the majority of patients with negative LNs had CC genotype, concerning the receptors status CC genotype associated with the presence of ER and PR.

Table V illustrates the correlation between both of MMP3 and MMP9 gene expression and patient's clinical characteristics. Regarding MMP3, the expression was significantly associated with positive $\mathrm{PR}$ and Her-2 $(\mathrm{P}=0.032$, $\mathrm{P}=0.034$ respectively). However, no significant link was found with the other characteristics. On the other hand, MMP9 was significantly associated with Her-2 receptor, but no other significant association between its expression and the other clinicoplathological parameters was noted. 
Table III. Distribution of MMP3 and MMP9 genotypes and alleles frequency in patients with BC and healthy females.

\begin{tabular}{|c|c|c|c|c|c|c|c|}
\hline Genes & Genotype & Patients, n $(\%)(\mathrm{n}=162)$ & Controls, $\mathrm{n}(\%)(\mathrm{n}=146)$ & $\chi^{2}$ & P-value & OR & $95 \% \mathrm{CI}$ \\
\hline \multirow[t]{3}{*}{ MMP3 } & $6 \mathrm{~A} / 6 \mathrm{~A}$ & $110(67.901)$ & $126(86.301)$ & 14.516 & $0.003^{\mathrm{a}}$ & Reference (1) & \\
\hline & $5 \mathrm{~A} / 6 \mathrm{~A}$ & $40(24.691)$ & $18(12.321)$ & 7.678 & $0.006^{\mathrm{a}}$ & $2.545^{\mathrm{a}}$ & $1.379-4.695$ \\
\hline & $5 \mathrm{~A} / 5 \mathrm{~A}$ & $12(7.407)$ & $2(0.69)$ & 6.452 & $0.011^{\mathrm{a}}$ & 5.760 & $1.267-26.187$ \\
\hline \multirow[t]{2}{*}{ Alleles } & $5 \mathrm{~A}$ & $64(19.753)$ & $22(7.534)$ & 19.089 & $<0.001^{\mathrm{a}}$ & $3.021^{\mathrm{a}}$ & $1.808-5.048$ \\
\hline & $6 \mathrm{~A}$ & $260(80.246)$ & $270(92.465)$ & & & 0.331 & $0.198-0.553$ \\
\hline \multirow[t]{3}{*}{ MMP9 } & $\mathrm{CC}$ & $137(84.567)$ & $130(89.042)$ & 1.332 & 0.249 & Reference (1) & \\
\hline & $\mathrm{CT}$ & $25(15.432)$ & $16(10.958)$ & & & 1.483 & $0.7573-2.9028$ \\
\hline & $\mathrm{TT}$ & $0(0)$ & $0(0)$ & & & & \\
\hline \multirow[t]{2}{*}{ Alleles } & $\mathrm{C}$ & $299(92.284)$ & $276(94.521)$ & 1.237 & 0.266 & 0.693 & $0.363-1.326$ \\
\hline & $\mathrm{T}$ & $25(7.716)$ & $16(5.479)$ & & & 1.442 & $0.754-2.759$ \\
\hline
\end{tabular}

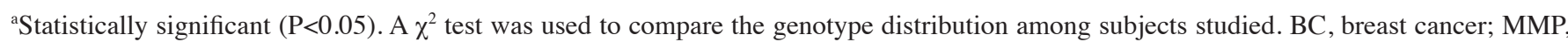
matrix metalloproteinase; OR, odds ratio.

Table IV. Associations of MMP3 and MMP9 genotypes with clinicopathological parameters of patients with BC.

\begin{tabular}{|c|c|c|c|c|c|}
\hline \multirow[b]{2}{*}{ Characteristics } & \multicolumn{3}{|c|}{ MMP3 genotypes } & \multicolumn{2}{|c|}{ MMP9 genotypes } \\
\hline & $5 \mathrm{~A} / 6 \mathrm{~A}$ & $6 \mathrm{~A} / 6 \mathrm{~A}$ & $5 \mathrm{~A} / 5 \mathrm{~A}$ & $\mathrm{CC}$ & $\mathrm{CT}$ \\
\hline \multicolumn{6}{|l|}{ Grade } \\
\hline II & 28 & 84 & 9 & 108 & 13 \\
\hline III & 16 & 22 & 3 & 29 & 12 \\
\hline$\chi^{2}$ & 3.905 & 3.364 & 0.001 & 8.05 & \\
\hline P-value & 0.049 & 0.061 & 0.980 & $0.005^{\mathrm{a}}$ & \\
\hline \multicolumn{6}{|c|}{ Axillary lymph node status } \\
\hline Negative & 28 & 35 & 4 & 59 & 8 \\
\hline Positive & 14 & 73 & 8 & 78 & 17 \\
\hline$\chi^{2}$ & 14.975 & 10.702 & 0.344 & 1.067 & \\
\hline P-value & $<0.001^{\mathrm{a}}$ & $0.001^{\mathrm{a}}$ & 0.557 & 0.302 & \\
\hline \multicolumn{6}{|l|}{ ER status } \\
\hline Negative & 17 & 33 & 4 & 42 & 12 \\
\hline Positive & 27 & 73 & 8 & 95 & 13 \\
\hline$\chi^{2}$ & 0.764 & 0.669 & $\geq 0.999$ & 2.682 & \\
\hline P-value & 0.382 & 0.414 & $\leq 0.001^{\mathrm{a}}$ & 0.091 & \\
\hline \multicolumn{6}{|l|}{ PR status } \\
\hline Negative & 23 & 37 & 5 & 51 & 14 \\
\hline Positive & 21 & 69 & 7 & 86 & 11 \\
\hline$\chi^{2}$ & 3.711 & 3.475 & 0.013 & 3.102 & \\
\hline P-value & 0.052 & 0.063 & 0.910 & 0.078 & \\
\hline \multicolumn{6}{|l|}{ Her-2 status } \\
\hline Negative & 31 & 76 & 10 & 96 & 21 \\
\hline Positive & 18 & 25 & 2 & 40 & 5 \\
\hline$\chi^{2}$ & 2.809 & 1.224 & 0.798 & 1.218 & \\
\hline P-value & 0.089 & 0.271 & 0.370 & 0.288 & \\
\hline
\end{tabular}

a Statistically significant $(\mathrm{P}<0.05) \cdot \chi^{2}$ test was used to study the association between genotypes and clinicopathological parameters. $\mathrm{BC}$, breast cancer; ER, estrogen receptor; MMP, matrix metalloproteinase; PR, progesterone receptor.

Survival analysis. The median of disease-free and overall survival rates showed no significant difference between the different genotypes of MMP3-1171 5A/6A and MMP9-1562

C> T SNPs (Fig. 3). 
Table V. Associations between MMP3 and MMP9 gene expression and clinicopathological parameters of patients with BC.

\begin{tabular}{|c|c|c|c|c|c|}
\hline Genes & Positive LNs & ER status & PR status & HER-2 status & Vascular invasion \\
\hline \multicolumn{6}{|l|}{ MMP3 } \\
\hline$\chi^{2}$ & 0.19 & 2.82 & 4.60 & 4.47 & 0.91 \\
\hline P-value & 0.66 & 0.09 & $0.03^{\mathrm{a}}$ & $0.03^{\mathrm{a}}$ & 0.34 \\
\hline \multicolumn{6}{|l|}{ MMP9 } \\
\hline$\chi^{2}$ & 0.81 & 0.40 & 0.01 & 5.43 & 0.42 \\
\hline $\mathrm{P}$-value & 0.37 & 0.53 & 0.91 & $0.02^{\mathrm{a}}$ & 0.52 \\
\hline
\end{tabular}

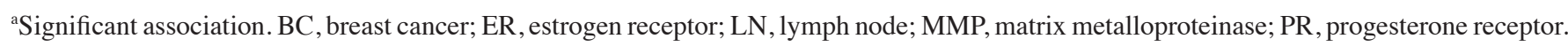
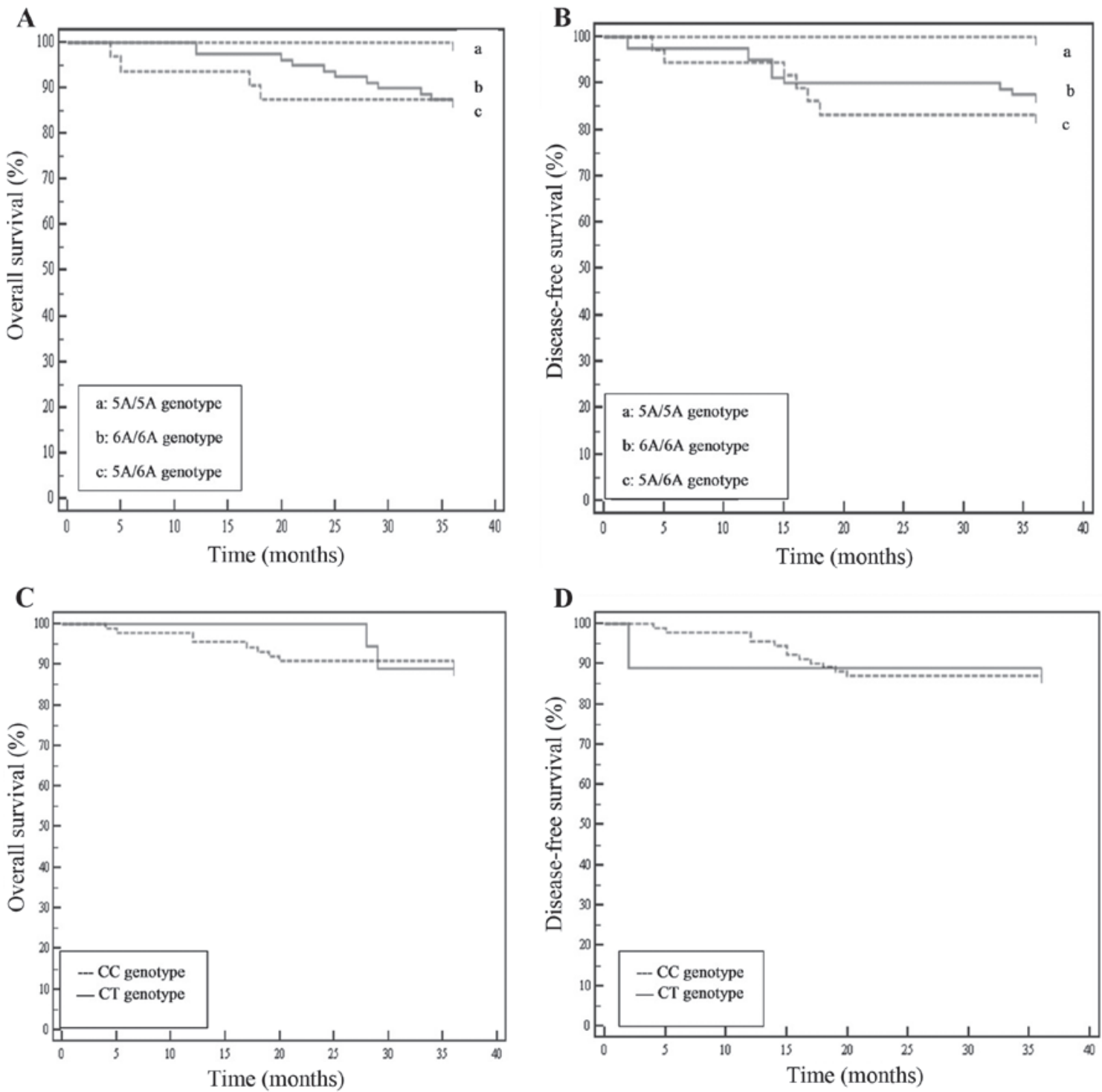

Figure 3. Survival analysis for MMP3 and MMP9 genotypes. (A) Overall and (B) disease-free survival for MMP3 genotypes. (C) Overall and (D) disease-free survival for MMP9 genotypes. Kaplan-Meier analysis was used to study the associations between the MMP3 and MMP9 genotypes and disease-free and overall survival rates. MMP, matrix metalloproteinase.

\section{Discussion}

Compared to western females, BC in Egyptian females may show some different characteristics, where the disease may have different clinical, pathological and molecular profiling (17). A suitable explanation of such inter-individuals variations of tumor characteristics may be obtained through analysis of different SNPs, which may also facilitate the 
prediction the patient's prognosis (8). Furthermore, and along with investigating the variations in gene expression, SNPs analysis may be promising predictive and prognostic markers, which may lead to better management of the disease (18).

Most of the reported SNPs in MMPs genes are functionally implicated in the progression of BC (19-21) particularly; those found in the promoter region and alter gene expression, which may result in imbalance in the MMP system, which, in turn, leads to excessive degradation of ECM and deregulation of ECM dynamics in cancer development (22).

The present study indicates that $5 \mathrm{~A} / 6 \mathrm{~A}$ and $5 \mathrm{~A} / 5 \mathrm{~A}$ genotypes of MMP3 are associated with an increased risk for developing $\mathrm{BC}$. These results are in line with previous findings of AbdRaboh in 2016, who reported that 5A allele is associated with increased risk of $\mathrm{BC}$ in a sample of $\mathrm{BC}$ patients in UAE (23). In addition, Padala in 2017, reported that 5A/6A genotype increased the risk of $\mathrm{BC}$ development among Indian population (22).

With regard to MMP9, the present results are consistent with that of Toroghi and his co-workers in 2017, who reported that MMP-9 polymorphism [-1562 C>T] is not associated with the BC incidence in the Iranian population (9). Many studies investigated the links connecting the MMP-9 promoter polymorphism [-1562 $\mathrm{C}>\mathrm{T}]$ with cancers. However, the published results are inadequate and inconclusive to confirm the relation of this SNP with the increased risk of cancer $(24,25)$. Lei et al (20) found a moderate increase in BC risk in TT homozygote genotype, whereas Przybylowska et al 2006 negated the association between $\mathrm{T}$ allele and cancer development (26). However, MMP9 polymorphism was found to act as genetic modifiers for the prognosis of $\mathrm{BC}$ in the Chinese population (27).

The present study reveals an insignificant upregulation of MMP3 expression but a significant upregulation of MMP9 expression in the BC patients. Such upregulation of both genes may be attributed to the fact saying that MMPs are greatly implicated in the cancer development and progression (28). Aberrant MMP expression is related to elevated risk of different types of cancers $(29,30)$. In addition, gene expression of MMP3 and MMP9 is reported to be up-regulated and to be implicated as prognostic marker in different types of cancers such as gastric, melanoma, lung, colorectal, and BC $(24,31,32)$.

The $5 \mathrm{~A}$ allele is associated with elevated transcriptional activity (33). However, insertion of an adenosine at the-1171 position in promoter region reduces its transcriptional activity to about half, as such insertion at the polymorphic site increases the binding affinity of the promoter for the repressor ZBP-89, which is one of the transcription factor that regulate the activity of the MMP3 gene expression (34). Moreover, the levels of both MMP3 mRNA and protein were reported to be significantly elevated in the skin tissue of individuals with $5 \mathrm{~A} / 5 \mathrm{~A}$ genotype than $6 \mathrm{~A} / 6 \mathrm{~A}$ individuals, and intermediate in 5A/6A heterozygotes individuals (35).

On the other side, several cis elements in the promoter region of MMP9 have been reported to regulate its expression at the transcription level. These include 2 AP- 1 sites (2533, and 279, bound by transcription factors c-Fos and c-Jun), a PEA3 motif (2540, recognized by transcription factor Ets), and a consensus sequence (2600) for binding of nuclear factor-kB. C- $1562 \mathrm{~T}$ polymorphic site is also an important regulatory element through acting as a binding site for transcription repressor proteins (36). Where, The C to $\mathrm{T}$ substitution at position-1562 in MMP-9 promoter region increases its transcriptional activity as T-allele lacks the ability of binding to the repressor protein (26). The $\mathrm{T}$ allele promotes $\mathrm{BC}$ progression through its enhancing effects on the MMP9 expression and activity, which, in turn, increases ECM degradation and invasion $(14,24)$.

Additionally, a direct association between increased expression of MMP9 protein and bad prognosis among BC patients (37) was reported. Furthermore, differential MMP9 expression modulates the degree of cellular differentiation and results in the increased aggressiveness of $\mathrm{BC}$ (38). This may be attributed to the fact saying that the- $1562 \mathrm{C} / \mathrm{T}$ and $-11716 \mathrm{~A} / 5 \mathrm{~A}$ SNPs in the MMP9 and MMP3 can modify the binding affinity of some transcription factors, leading, in turn, to alteration in their gene expression $(39,40)$. Moreover, the up regulation of MMP3 and MMP9 expression resulting from high transcriptional activity of either $5 \mathrm{~A}$ allele or $\mathrm{T}$ allele may promote the development and growth of various malignancies $(31,41)$.

The results of survival analysis are in accordance with the finding of Padala et al (22), who reported decreased survival rate associated with risk genotypes of MMP3 and MMP9 SNPs, while statistically, it is insignificant. In addition Song et al (42) reported a positive association between the expression of MMP9, the increased risk of cancer recurrence and the reduced the survival rates of $\mathrm{BC}$ patients.

To the best of our knowledge, this is the first study to investigate the association of $M M P-3$ promoter-1171 5A/6A, MMP-9 promoter-1562C $>\mathrm{T}$ SNPs and the risk of $\mathrm{BC}$ among Egyptians. It was found that $1171-5 \mathrm{~A} / 6 \mathrm{~A}$ MMP3 SNP is associated with an increased risk of BC. However, polymorphism in MMP9 is not associated with the risk. In addition, the absence of homozygous TT genotype among the study population may indicate the importance of studying SNPs among different populations as the genetic composition was reported to be greatly varied from one population to another.

\section{Acknowledgements}

Not applicable.

\section{Funding}

No funding was received.

\section{Availability of data and materials}

The datasets used and/or analyzed during the present study are available from the corresponding author on reasonable request.

\section{Authors' contributions}

FAERI designed the study and wrote the protocol with the assistance of MH and NAAEM. NAEI collected the samples and participated in the laboratory investigations. NAAEM and ME interpreted the clinical data of patients. FAERI and SEE contributed to laboratory investigations and statistical analysis. MAE provided the laboratory equipment and consultation as well as interpretation of results. FAERI wrote the manuscript 
and NAAEM and MH proofread it. All authors provided advice and approved the final manuscript.

\section{Ethics approval and consent to participate}

The research methodology in the present work was approved by Research Ethical Committee of the Medical Research Institute, Alexandria University (10RG \#:10RG0008812; Alexandria, Egypt) and written informed consent was obtained from each participant enrolled in the study prior to sample collection. Experimental procedures and sampling followed the international and national regulations in accordance with the Declaration of Helsinki.

\section{Patient consent for publication}

Not applicable.

\section{Competing interests}

The authors declare that they have no competing interests.

\section{References}

1. Bray F, Ferlay J, Soerjomataram I, Siegel RL, Torre LA and Jemal A: Global cancer statistics 2018: GLOBOCAN estimates of incidence and mortality worldwide for 36 cancers in 185 countries. CA Cancer J Clin 68: 394-424, 2018.

2. DeSantis CE, Bray F, Ferlay J, Lortet-Tieulent J, Anderson BO and Jemal A: International variation in female breast cancer incidence and mortality rates. Cancer Epidemiol Biomarkers Prev 24: 1495-1506, 2015.

3. Ibrahim AS, Khaled HM, Mikhail NN, Baraka H and Kamel H: Cancer incidence in Egypt: Results of the national population-based cancer registry program. J Cancer Epidemiol 2014 $437971,2014$.

4. Michailidou K, Hall P, Gonzalez-Neira A, Ghoussaini M, Dennis J, Milne RL, Schmidt MK, Chang-Claude J, Bojesen SE, Bolla MK, et al: Large-scale genotyping identifies 41 new loci associated with breast cancer risk. Nat Genet 45: 353-361, 361e1-e2, 2013.

5. Garcia-Closas M, Couch FJ, Lindstrom S, Michailidou K, Schmidt MK, Brook MN, Orr N, Rhie SK, Riboli E, Feigelson HS, et al: Genome-wide association studies identify four ER negative-specific breast cancer risk loci. Nat Genet 45 392-398, 398e1-e2, 2013.

6. Deng N, Zhou H, Fan H and Yuan Y: Single nucleotide polymorphisms and cancer susceptibility. Oncotarget 8: 110635-110649, 2017.

7. Sternlicht MD, Bissell MJ and Werb Z: The matrix metalloproteinase stromelysin-1 acts as a natural mammary tumor promoter. Oncogene 19: 1102-1113, 2000.

8. Verma S, Kesh K, Gupta A and Swarnakar S: An overview of matrix metalloproteinase 9 polymorphism and gastric cancer risk. Asian Pac J Cancer Prev 16: 7393-7400, 2015.

9. Toroghi F, Mashayekhi F, Montazeri V, Saedi HS and Zivar S: Association of MMP-9 promoter polymorphism and breast cancer among Iranian patients. Eur J Oncol 22: 38-42, 2017.

10. Liu D, Guo H, Li Y, Xu X, Yang K and Bai Y: Association between polymorphisms in the promoter regions of matrix metalloproteinases (MMPs) and risk of cancer metastasis: A meta-analysis. PLoS One 7: e31251, 2012.

11. Li X, Qu L, Zhong Y, Zhao Y, Chen H and Daru L: Association between promoters polymorphisms of matrix metalloproteinases and risk of digestive cancers: A meta-analysis. J Cancer Res Clin Oncol 139: 1433-1447, 2013.

12. Okamoto K, Ishida C Ikebuchi Y, Mandai M, Mimura K Murawaki Y and Yuasa I: The genotypes of IL-1 beta and MMP-3 are associated with the prognosis of HCV-related hepatocellular carcinoma. Intern Med 49: 887-895, 2010.

13. Motovali-Bashi M, Hojati Z and Hajihoseiny S: The role of matrix metalloproteinase-3 functional $5 \mathrm{~A} / 6 \mathrm{~A}$ promoter polymorphism in tumor cell progression and metastasis of breast cancer. Iran J Biotechnol 6: 45-9, 2008

14. Sadeghi M, Motovali-bashi M and Hojati Z: MMP-9 promoter polymorphism associated with tumor progression of breast cancer in Iranian population. Int J Integrat Biol 6: 33-37, 2009.
15. Gencer S, Cebeci A and Irmak-Yazicioglu MB: Matrix metalloproteinase gene expressions might be oxidative stress targets in gastric cancer cell lines. Chin J Cancer Res 25: 322-333, 2013.

16. Livak KJ and Schmittgen TD: Analysis of relative gene expression data using real-time quantitative PCR and the 2(-Delta Delta C(T)) method. Methods 25: 402-408, 2001.

17. Chouchane L, Boussen H and Sastry KS: Breast cancer in Arab populations: Molecular characteristics and disease management implications. Lancet Oncol 14: e417-e424, 2013.

18. Blons H, Gad S, Zinzindohoué F, Manière I, Beauregard J, Tregouet D, Brasnu D, Beaune P, Laccourreye O and Laurent-Puig P: Matrix metalloproteinase 3 polymorphism: A predictive factor of response to neoadjuvant chemotherapy in head and neck squamous cell carcinoma. Clin Cancer Res 10: 2594-2599, 2004.

19. Ding C, Chen X,Zhang PT, Huang JP, Xu Y, Chen N and Zhong LJ: Matrix Metalloproteinase-3-1171 5A/6A Polymorphism (rs35068180) is Associated with Risk of Periodontitis. Sci Rep 5: $11667,2015$.

20. Lei H, Hemminki K, Altieri A, Johansson R, Enquist K, Hallmans G, Lenner P and Försti A: Promoter polymorphisms in matrix metalloproteinases and their inhibitors: Few associations with breast cancer susceptibility and progression. Breast Cancer Res Treat 103: 61-69, 2007.

21. Srivastava P, Gangwar R, Kapoor R and Mittal RD: Bladder cancer risk associated with genotypic polymorphism of the matrix metalloproteinase-1 and 7 in North Indian population. Dis Markers 29: 37-46, 2010.

22. Padala C, Tupurani MA, Puranam K, Gantala S, Shyamala N, Kondapalli MS, Gundapaneni KK, Mudigonda S, Galimudi RK, Kupsal K, et al: Synergistic effect of collagenase-1 (MMP1), stromelysin-1 (MMP3) and gelatinase-B (MMP9) gene polymorphisms in breast cancer. PLoS One 12: e0184448, 2017.

23. Abdraboh NR and Bayoumi FA: Gene polymorphism of matrix metalloproteinases 3 and 9 in breast cancer. Gene Rep 5: 151-156, 2016.

24. Chiranjeevi P, Spurthi KM, Rani NS, Kumar GR, Aiyengar TM, Saraswati M, Srilatha G, Kumar GK, Sinha S, Kumari CS, et al: Gelatinase B $(-1562 \mathrm{C} / \mathrm{T})$ polymorphism in tumor progression and invasion of breast cancer. Tumour Biol 35: 1351-1356, 2014.

25. Chaudhary AK, Pandya S, Mehrotra R, Singh M and Singh M: Role of functional polymorphism of matrix metalloproteinase-2 $(-1306 \mathrm{C} / \mathrm{T}$ and $-168 \mathrm{G} / \mathrm{T})$ and MMP-9 (-1562 C/T) promoter in oral submucous fibrosis and head and neck squamous cell carcinoma in an Indian population. Biomarkers 16: 577-586, 2011.

26. Przybylowska K, Kluczna A, Zadrozny M, Krawczyk T, Kulig A, Rykala J, Kolacinska A, Morawiec Z, Drzewoski J and Blasiak J: Polymorphisms of the promoter regions of matrix metalloproteinases genes MMP-1 and MMP-9 in breast cancer. Breast Cancer Res Treat 95: 65-72, 2006.

27. Fu F, Wang C, Chen LM, Huang M and Huang HG: The influence of functional polymorphisms in matrix metalloproteinase 9 on survival of breast cancer patients in a Chinese population. DNA Cell Biol 32: 274-282, 2013

28. Amălinei C, Căruntu ID, Giuşcă SE and Bălan RA: Matrix metalloproteinases involvement in pathologic conditions. Rom $\mathbf{J}$ Morphol Embryol 51: 215-228, 2010.

29. Fan SH, Wang YY, Lu J, Zheng YL, Wu DM, Zhang ZF, Shan Q, Hu B, Li MQ and Cheng W: CERS2 suppresses tumor cell invasion and is associated with decreased V-ATPase and MMP-2/MMP-9 activities in breast cancer. J Cell Biochem 116: $502-513,2015$.

30. Tabouret E, Bertucci F, Pierga JY, Petit T, Levy C, Ferrero JM, Campone M, Gligorov J, Lerebours F, Roché $\mathrm{H}$, et al: MMP2 and MMP9 serum levels are associated with favorable outcome in patients with inflammatory breast cancer treated with bevacizumab-based neoadjuvant chemotherapy in the BEVERLY-2 study. Oncotarget 7: 18531-18540, 2016.

31. Jafari M, Pirouzi A, Mohsenzadeh M, Kusari AA and Hajihosseini S: Association of MMP 9-1562C/T single nucleotide polymorphism with the susceptibility to lung cancer disease in South Iranian population. J Med Med Res 4: 2494-2502, 2014.

32. McColgan P and Sharma P: Polymorphisms of matrix metalloproteinases $1,2,3$ and 9 and susceptibility to lung, breast and colorectal cancer in over 30,000 subjects. Int $\mathbf{J}$ Cancer 125: 1473-1478, 2009 
33. Yang X, Hu JW, Qiu MT, Li M, Yin R, Wang J, Xu L and Zhang Q: Association of matrix metalloproteinase-3-1171 (5A $>6 \mathrm{~A})$ polymorphism with cancer risk: A meta-analysis of 41 studies. PLoS One 9: e87562, 2014.

34. Fanjul-Fernández M, Folgueras AR, Cabrera S and López-Otín C: Matrix metalloproteinases: Evolution, gene regulation and functional analysis in mouse models. Biochim Biophys Acta 1803: 3-19, 2010.

35. Medley TL, Kingwell BA, Gatzka CD, Pillay P and Cole TJ: Matrix metalloproteinase-3 genotype contributes to age-related aortic stiffening through modulation of gene and protein expression. Circ Res 92: 1254-1261, 2003.

36. Zhang B, Ye S, Herrmann SM, Eriksson P, de Maat M, Evans A, Arveiler D, Luc G, Cambien F, Hamsten A, et al: Functional polymorphism in the regulatory region of gelatinase $\mathrm{B}$ gene in relation to severity of coronary atherosclerosis. Circulation 99: 1788-1794, 1999.

37. Youssef NS and Hakim SA: Association of Fascin and matrix metalloproteinase-9 expression with poor prognostic parameters in breast carcinoma of Egyptian women. Diagn Pathol 9: 136, 2014.

38. Yousef EM, Tahir MR, St-Pierre Y and Gaboury LA: MMP-9 expression varies according to molecular subtypes of breast cancer. BMC Cancer 14: 609, 2014.
39. Jormsjö S, Whatling C, Walter DH, Zeiher AM, Hamsten A and Eriksson P: Allele-specific regulation of matrix metalloproteinase-7 promoter activity is associated with coronary artery luminal dimensions among hypercholesterolemic patients. Arterioscler Thromb Vasc Biol 21: 1834-1839, 2001.

40. Rahimi Z, Yari K and Rahimi Z: Matrix metalloproteinase-9-1562T allele and its combination with MMP-2-735 $\mathrm{C}$ allele are risk factors for breast cancer. Asian Pac J Cancer Prev 16: 1175-1179, 2015.

41. Sugimoto M, Yoshida S, Kennedy S, Deguchi M, Ohara N and Maruo T: Matrix metalloproteinase-1 and -9 promoter polymorphisms and endometrial carcinoma risk in a Japanese population. J Soc Gynecol Investig 13: 523-529, 2006.

42. Song J, Su H, Zhou YY and Guo LL: Prognostic value of matrix metalloproteinase 9 expression in breast cancer patients: A meta-analysis. Asian Pac J Cancer Prev 14: 1615-1621, 2013. 